\title{
Extrém hosszú tartamú 1-es típusú diabetes mellitus ritka esete
}

\author{
Fövényi József dr. \\ Péterfy Sándor Utcai Kórház-Rendelőintézet és Manninger Jenő Országos Traumatológiai Intézet, \\ Diabetes Szakrendelö, Budapest
}

\begin{abstract}
Az 1-es típusú diabetes mortalitása, bár csökkenő tendenciát mutatva, jelentősen meghaladja a standard mortalitást. Ez egyúttal a diabetesszel megélt életévek rövidülésével jár együtt. Az esetismertetés tárgya egy 86 éves diabetestartammal a 9l. életévét megélő nőbeteg, akit több mint 55 éven keresztül egyetlen orvos - a szerző - kezelt/gondozott. Az 1932-ben, ötéves korában fellépett diabetest először naponta háromszor adagolt gyors hatású inzulinnal, majd 1940-tól kezdve naponta egyszer alkalmazott gyors hatású és cink-protamin inzulinnal, később sertés, majd humán kristályos cinkinzulinnal, majd az utolsó 16 évben gyors hatású NPH-inzulin keverékével kezelték. Ennek oka az volt, hogy a beteg rögeszmésen ragaszkodott a napi egyszeri inzulinadáshoz, és hogy esetében mindegyik inzulin hatástartama 24 órásnak bizonyult. Az évtizedeken át folyamatosan túladagolt egyszeri inzulinadás következménye a szinte naponta, fóként az éjjeli órákban fellépő hypoglykaemia lett, következményes nagyfokú vércukor-ingadozásokkal. Az 1930-as évek közepétől a hatvanas évekig polarimetriás, majd száraz kémiás módszerrel vizeletcukor-önellenőrzést végzett a nyolcvanas évek elejéig, majd áttért a vércukor-önellenőrzésre. Az ötvenes években két sikertelen terhessége volt, 2010-11-ben egymás után jobb, majd bal oldali combnyaktörést szenvedett, majd mindkét szemén megmútötték a cataractáját. Az utolsó 25 évben $\mathrm{HbA}_{1 \mathrm{c}}$-szintje 7\% körül mozgott. Sem retinopathia, sem nephropathia nem fejlődött ki nála, csupán súlyos neuropathia okozott panaszokat az utolsó években. Emellett időskori száraz maculadegeneratiója miatt látása folyamatosan romlott. Elnyerte a 'Joslin 75' medált is. Élete utolsó két hónapjában engedte, hogy degludek + glulizin inzulinnal intenzíven kezeljék. Halálát myocardialis infarctus okozta. Bár a vércukor-ingadozások minimalizálása és a tartósan jó anyagcsere-vezetés jelentősen javítja a diabetesesek életkilátásait, esetünkben jó fél évszázadon keresztül egyik sem állt fenn. Ezért az extrém hosszú diabetestartamra nem találtunk magyarázatot.
\end{abstract}

Orv Hetil. 2020; 161(5): 193-197.

Kulcsszavak: 1-es típusú diabetes, napi egyszeri inzulinadás, extrém hosszú diabetestartam

\section{Extreme long duration of type 1 diabetes mellitus}

Mortality in type 1 diabetes, although showing a declining trend, is significantly higher than standard mortality. The case study focuses on a woman who lived for 91 years; she was insulin-dependent for 86 years and has been treated by a single physician - the author - for over 55 years. She was diagnosed with diabetes in 1932 at the age of five. Her diabetes was first treated with rapid-acting insulin three times daily, then from 1940 with rapid-acting and protamine zinc insulin once daily, while later on pork, then human crystalline zinc insulin was used, followed by a mixture of rapid-acting and NPH insulin for the last 16 years. The reason behind the above treatment regimen was that the patient obsessively insisted on a once daily insulin dose and the duration was shown to be 24 hours for each insulin. The continuous overdose of a single insulin for decades has resulted in hypoglycemic episodes almost daily, with consequent high fluctuations in blood glucose levels. She performed urine glucose tests using a polarimeter from the mid-1930s to the sixties, then used test strips until the early eighties, and later switched to blood glucose self-testing. Her $\mathrm{HbA}_{1 \mathrm{c}}$ levels have been around $7 \%(53 \mathrm{mmol} / \mathrm{mol})$ for the last 25 years. She did not develop retinopathy or nephropathy, only severe neuropathy caused complaints during the last years of her life. In addition, her vision continued to deteriorate due to age-related dry macular degeneration. She is a Joslin 75-year medalist. For the last two months of her life, she gave permission for degludec + glulisine insulin intensive treatment. Her death was caused by myocardial infarction. Although minimizing blood glucose fluctuations and sustaining good metabolic control significantly improve the life expectancy of people with diabetes, in our case neither has existed for well over half a century. Therefore, no explanation was found for the extremely long duration of diabetes and longevity. 
Keywords: type 1 diabetes, once daily insulin, extreme long diabetes duration

Fövényi J. [Extreme long duration of type 1 diabetes mellitus]. Orv Hetil. 2020; 161(5): 193-197.

(Beérkezett: 2019. október 15.; elfogadva: 2019. október 30.)

\section{Rövidítések}

$\mathrm{CRP}=$ C-reaktív protein $;$ DCCT-EDIC $=($ Diabetes Control and Complication Trial-Epidemiology of Diabetes Interventions and Complications) a cukorbetegség elleni védekezés és szövődményvizsgálat - a cukorbetegség intervencióinak és szövődményeinek epidemiológiája; $\mathrm{E}$ = egység; GFR = glomerulusfiltrációs ráta; $\mathrm{HbA}_{\mathrm{lc}}=$ hemoglobin-A-lc; $\mathrm{HDL}=($ highdensity lipoprotein) magas sûrűségü lipoprotein; LDL = (low-density lipoprotein) alacsony sürúségü lipoprotein; NPH $=($ neutral protamine Hagedorn $)$ neutrális protamin Hagedorn szerint készítve; SMR = (standardised mortality ratio) standardizált mortalitási ráta

Az l-es típusú diabetes mortalitási kockázata az irodalmi adatok tükrében rendkívül széles skálán mozog. Az egyik végletet képezi a DCCT-EDIC vizsgálat, melynél a DCCT keretében intenzív inzulinkezelésben részesülők standard mortalitási rátája (SMR) 0,88 volt, a konvencionálisan kezelteké valamivel meghaladta az átlagpopulációét, a 27 éves megfigyelési idő alatt pedig az egész DCCT-EDIC vizsgálatban részt vevőké 1 körülinek, azaz a nem diabetesesekével azonosnak bizonyult [1]. A másik végletet egy japán-finn közös vizsgálatban a japán SMR képezte 12,9-es értékkel, szemben a finn 3,9-es SMR-rel [2]. Az Allegheny County Type 1 Diabetes Registry kohorsz-utánvizsgálata során a gyermekkorban diagnosztizált 1-es típusú diabetesesek halálozási kockázata a nem diabeteses kortársaikhoz képest 9-szeresnek bizonyult, bár a később diagnosztizáltaknál - 28-43 éves diabetestartam között - ez a kockázat 7,4-szeresre csökkent [3]. Az európai vizsgálatok ennél lényegesen jobb - 2-4-szeres - SMR-ról számolnak be [4-6].

Mindezekből következik, hogy az l-es típusú diabetesesek várható élettartama elmarad a nem diabeteses kortársaikétól, ez viszont az elmúlt évszázad során - elsősorban az inzulinnak a terápiába történő bevezetését követően - drámaian javult. Amíg a preinzulinérában a 10 évesnél fiatalabb diabeteses gyermekek átlag 2,6 évig éltek, ez a 10 év alatti életkorban 1922 és 1926 között diabetesben megbetegedettek esetében 14,3 évre, az 1926 és 1928 között fellépő diabetesnél 31,9 évre, az 1929 és 1938 között diabetesessé vált gyerekeknél 39,8 évre emelkedett [7]. A Pittsburgh-vizsgálatban az 1950 és 1964 között 5 éves korban fellépő diabetesben 49 évre becsülték a várható élettartamot, mely az 1965 és 1980 között hasonló korúaknál fellépő diabetesben már 63,8 évre nőtt [8].
A fenti adatok ellenére egyes, gyermekkoruk óta diabeteses egyének - igaz, nem nagy számban - hosszabb diabetestartamot és ezzel együtt magasabb életkort érhetnek meg. 1970-tôl a Joslin Diabetes Központ több mint 5000, 50 évnél hosszabb, több mint 90, 75 évnél hosszabb és 1, 80 éves diabetestartammal rendelkező 1-es típusú diabetesest regisztrált és tüntetett ki oklevéllel és medállal. A kitüntetettek 18 országban élnek/éltek [9]. Nagyon valószínú, hogy világszerte a fenti számokon túl még nagyon sok l-es típusú diabeteses rendelkezik több mint 50, illetve 75 éves diabetestartammal, ugyanis az adatok csupán 17-18 országból származnak. Ami hazánkat illeti, közel 10 beteg kapott eddig '50 éves', 2 pedig '75 éves' medált. Közülük az egyik 7 évvel ezelőtt, a másik pedig - aki e közlemény főszereplője - 1 éve hunyt el. Megjegyzendő még, hogy e dolgozat szerzője 5,50 évnél hosszabb betegségtartammal bíró beteget gondoz. Eddig egyikőjük se kérte a Joslin-medált.

\section{Esetismertetés}

A jómódú budai polgári családban született leány 1927 májusában látta meg a napvilágot. Még születése előtt elhunyt 1-es típusú diabeteses anyai nagybátyja 22 éves korában, valószínúleg ketoacidosisos kómában. Nővére agydaganat miatt huszonévesen halt meg, szülei nem érték meg a 70. életévüket, tehát a család egyetlen tagja sem volt hosszú életü. Ötéves korában, 1932-ben lépett fel nála a diabetes, melyet azonnal napi háromszor adagolt, akkor „sima” (,alt”, „regular”) inzulinnak nevezett sertés-marha kevert gyors hatású inzulinnal kezdtek kezelni. Még a harmincas évek közepén édesapja beszerzett egy Zeiss polarimétert, és a három frakcióban gyújtött vizeletét naponta háromszor polározták, majd az inzulin adagját a kapott vizeletcukor-értékekhez igazították. A negyvenes évek elején naponta egyszeri cink-protamin és gyors hatású inzulin keverékére váltottak. A későbbi inzulinterápiájáról a továbbiak során lesz szó. A harmincas években, egészen a negyvenes évek végéig maximum 60-70 g szénhidrátot tartalmazó, az akkor szokásos ketogén diétát tartott.

Ami az önellenőrzést illeti: a polarimetriás vércukorönellenőrzést egészen a hatvanas évek közepéig folytatta, majd áttért az akkor már Magyarországon is elérhető száraz kémiai vizeletcukor-meghatározásra, Diastix-csíkokat (Bayer AG, Leverkusen, Németország) használva. Az országban az elsők között 1982-ben kezdte el az otthoni vércukor-önellenőrzést, először Dextrostix-csíkok- 
kal, majd a technika fejlődésével párhuzamosan mindig a legkorszerúbb eszközöket használva, haláláig.

Kezdettől fogva nagyon szabados nevelésben részesült. A diabetest és a vele járó terheket leszámítva a többi, egészséges gyerekhez hasonlóan élt, több sportot is űzött egyszerre, mint kerékpározás, lovaglás, tenisz, röplabda, úszás, korcsolyázás. A rendszeres napi tornázást élete végéig megtartotta. Alkatilag a soványak közé számított, testtömegindexe utolsó életévében is csak 23,9 $\mathrm{kg} / \mathrm{m}^{2}$ volt. Szubkután zsírszövete szinte teljesen hiányzott, leszámítva azt az egy-egy tenyérnyi területet combjai elülső felszínén, ahova az inzulint mindig is adagolta.

1952-ben ment férjhez. Férje imádta és gyakorlatilag az egész életét neki szentelte. A 2000-es évek elején bekövetkezett halála előtt elmondta, hogy több évtizeden át félig ébren aludt, és felesége kezét megfogva figyelte, hogy nem lép-e fel nála hypoglykaemia, ami az akkori napi egyszeri inzulin-túladagolása miatt szinte minden éjjel bekövetkezett. A feleség annyira megszokta, hogy gyermekkora óta kényeztetik, hogy a későbbiekben is mindig ragaszkodott - sokszor irreális - elképzeléseihez, még gondozóorvosával is szembehelyezkedve. 1957ben és 1959-ben két ízben esett teherbe, de első alkalommal magzata méhen belül elhalt, második alkalommal a 36. terhességi héten leánygyermeket szült, aki csak egy napig élt. Ezt a traumát élete végéig nem tudta kiheverni.

A szerző kétéves diplomás orvosként a Fővárosi János Kórház II. Belosztályán 1962 végén találkozott először a beteggel, aki azonnal kezelő/gondozó orvosának választotta, és több mint 55 éven át, haláláig megtartotta. Osztályos felvételére 15 év alatt a János Kórházban egy alkalommal, 1967-ben került sor. Akkor összesen napi 60 E inzulint adagolt, fele-fele arányban gyors hatású és cink-protamin, később sertés, majd humán kristályos cinkinzulint. Akkor 35 éves diabetestartam után semmilyen diabeteses szövődményt nem tudtak kimutatni nála. A János Kórházat követően gondozása 1978-tól 2001-ig a fơvárosi Péterfy Sándor Utcai Kórház 'B' Belosztályán, a szerző nyugdíjba vonulását követően pedig a Diabetes Szakrendelésen folytatódott. A Péterfy Kórházban egy ízben, 1988-ban került sor hospitalizációjára, amikor két alkalommal C-peptid-vizsgálatot is végeztek, de nem volt mérhető saját inzulintermelése.

Még 2008-ban, a több mint 75 éve komoly diabeteses szövődmények nélküli diabetestartamával elsőként az országból megkapta a 'Joslin 75' medált (1. ábra), melyre nagyon büszke volt.

Az ezredfordulót követően 2009-ben és 2010-ben egymás után lakásában elesett, és mindkét combnyakát eltörte, de a mütéteket követően felépült, csupán bottal közlekedett tovább. 2012-ben mindkét oldali cataractáját megmúttette, ennek ellenére látása folyamatosan romlott az időskori száraz maculadegeneratiójának progressziója következtében. (Diabeteses retinopathiára utaló jeleket egyetlen alkalommal sem észleltek.) Ez a későb-

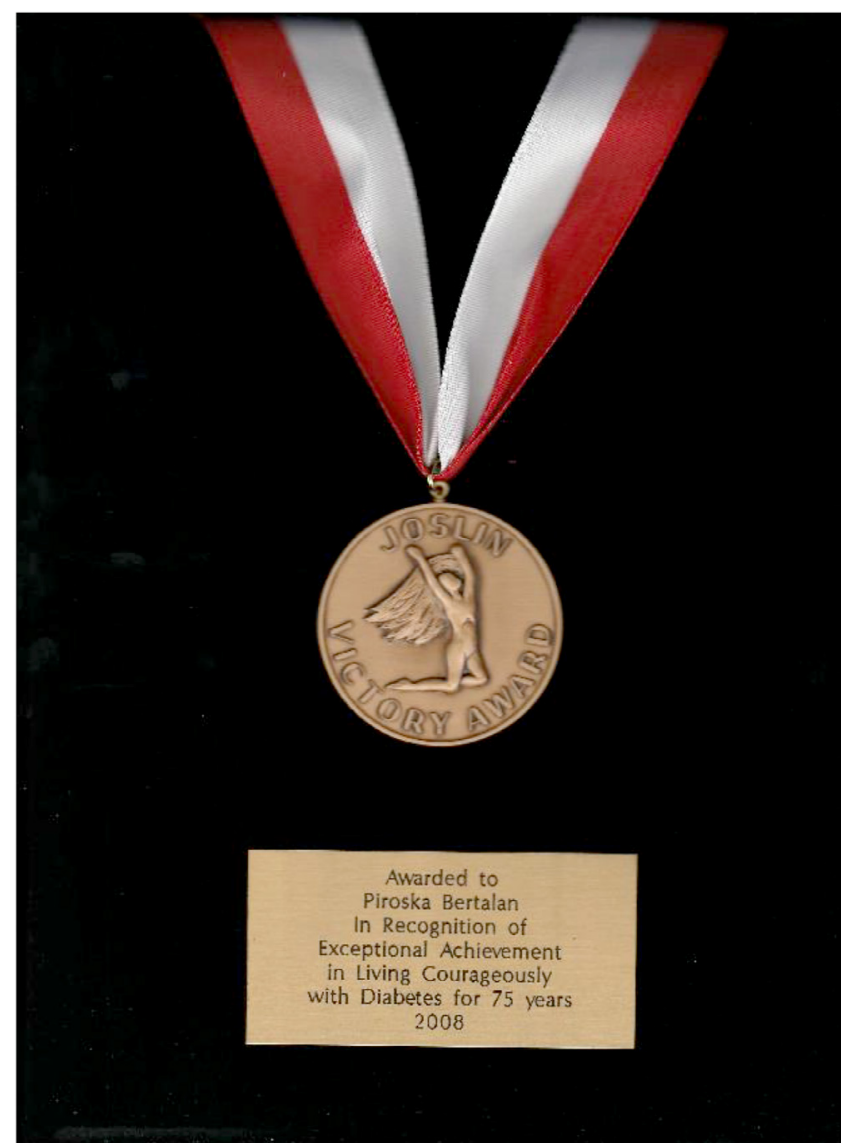

1. ábra

A 'Joslin 75' medál

biek során egyre jobban megnehezítette az önmenedzselését is.

Rendkívül fontos, hogy kissé részletesebben foglalkozzunk az inzulinterápiájával. Élete utolsó két és fél hónapja kivételével nem járult hozzá, hogy a korszerű inzulinkezelés bármely formáját alkalmazza. Hogy ebbe gondozóorvosa kényszerüen beleegyezett, annak oka az volt, hogy a kristályos cinkinzulint felváltó előkevert NPH gyors hatású inzulinok napi egyszeri alkalmazásakor esetében egyértelmú volt a 24 órás hatástartam. Ezt vércukor-ellenőrzéssel, majd önellenőrzéssel mindig sikerült igazolni. Miután vércukrát viszont naponta 5-10 alkalommal ellenőrizte, minden kiugrást 1-2 E liszpro inzulin beadásával korrigált, fóként a déli és az esti órákban, bár erre hetente maximum 2-3 esetben került sor. A napi egyszeri inzulinadagja két évtizeden át $22 \mathrm{E}$ körül alakult, ami 0,3 E/testsúlykg-nak felelt meg. Még az analóg inzulinkeverékek használatát is visszautasította. Vércukornaplót soha nem vezetett, értékeit glükométere memóriájából lehetett kontrollálni.

Ezzel elérkeztünk a diétás problémáihoz. Ha az éhomi vércukor 8-10 mmol/1 közelében volt, kitolta a reggeli időpontját akár 11 óráig, vércukrát óránként ellenőrizve. Főtt ételt ritkán evett, napi kb. 150 g szénhidrátja nagy részét zsemle formájában fogyasztotta el; húst nagyon keveset, zöldséget, gyümölcsöt alig evett. Tehát az afiziológiás és korszerütlen inzulinterápiája mellett étkezése 


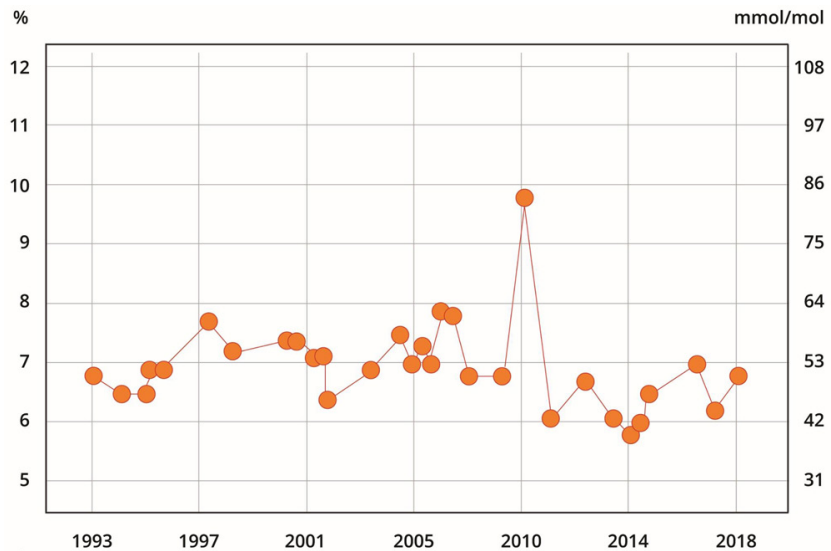

2. ábra $\mid \mathrm{A} \mathrm{HbA}_{\mathrm{lc}}$-értékek az elmúlt 25 év során

is rendkívül hiányos, egészségesnek biztosan nem nevezhetô volt.

Ennek ellenére 1993 óta fennmaradt összes $\mathrm{HbA}_{\mathrm{lc}}$ értéke 7\% körül mozgott, időnként 6\% alá süllyedve (2. ábra). Egyetlen alkalommal, 2010-ben ugrott fel 10\%-ra. Ennek oka az volt, hogy az új glükométerével már nem tudta a mg\%-os skálát használni - melyet hét évtizeden át megszokott -, és a mmol/l-es értékeket félreértelmezte, például a $10 \mathrm{mmol} / \mathrm{l}$-t $100 \mathrm{mg} \%$-nak gondolva, csökkentette az inzulinadagjait. A hiba felfedése és kiküszöbölése után $\mathrm{HbA}_{\mathrm{lc}}$-értékei normalizálódtak. Időközben a megromlott látása és egyetlen diabeteses szövődményként kimutatott és komoly alszári panaszokat (fóként éjjel zsibbadás, nyilalló fájdalom a lábakban) okozó súlyosbodó neuropathiája - mely alfa-glükonsav és pregabalin adására nem javult - egyre jobban megnehezítette az önmenedzselését.

A kezelésével/gondozásával kapcsolatos komoly problémák 2017 őszén bontakoztak ki. Ennek oka az volt, hogy bár vércukorértékeit naponta 8-10 alkalommal mérte (a neuropathia miatt nem érezte az ujjszúrás okozta fájdalmat), korábban stabilan $4-10 \mathrm{mmol} / 1$ között mozgó vércukorértékei erősen ingadozni kezdtek. Ennek hátterében az állt, hogy sérült látása miatt a vércukormérésben egyre többször hibázott, az inzulin beadásakor pedig sokszor derékszögben elgörbült a pen túje, amit szintén nem vett észre, és ilyenkor nem jutott inzulin a szervezetébe. Ez 2018-ig olyan mértékben súlyosbodott, hogy szükségessé vált hospitalizációja kórházunk II. Belosztályán. Még ekkor is ragaszkodott a 25 : 75-ös gyors hatású inzulinkeverék alkalmazásához, melyből 18 E-gel biztosítani sikerült a közel normális anyagcseréjét. Hazatérése után viszont a problémák újra jelentkeztek, és a következő két és fél hónapon belül súlyos hypoglykaemiák miatt még 6 alkalommal vált szükségessé újbóli kórházi felvétele. Tehát az utolsó tavasz folyamán összesen 57 napot töltött kórházban. Az ekkor mért laborparaméterei: vörösvértest: 3,4 T/1, Hb: 102 $\mathrm{g} / \mathrm{l}$, fehérvérsejt: 7,4 G/l, kreatinin: $64 \mu \mathrm{mol} / \mathrm{l}$, GFR: $79 \mathrm{ml} / \mathrm{min} / 1,73 \mathrm{~m}^{2}$, összkoleszterin: $4,2 \mathrm{mmol} / \mathrm{l}$, HDL-koleszterin: $1,5 \mathrm{mmol} / 1$, triglicerid: $0,8 \mathrm{mmol} / 1$,
LDL-koleszterin: 2,24 mmol/l, CRP: $57 \mathrm{mg} / \mathrm{l}, \mathrm{HbA}_{\mathrm{lc}}$ $6,8 \%, 51 \mathrm{mmol} / \mathrm{mol}$. Tehát az anaemián és gyulladásra utaló jeleken kívül diabeteses szövődményként értékelhetô eltérés nem volt.

Május hóban a beteg hazatért, és nagyon erôs rábeszélésre beleegyezett a lakásán történő 24 órás gondozásba. A vércukor-ellenőrzésre, inzulinadásra és diétára kioktatott gondozónő jelenléte mellett a beteg állapota rohamosan javulni kezdett, étvágya nőtt, naponta rendszeresen tornázott, beleértve guggolásos gyakorlatokat. Vércukorértékei 5-7 mmol/1 között stabilizálódtak hypoglykaemiái megszúntek - a két hónapja alkalmazott degludek és glulizin inzulin adása mellett. Utolsó inzulinadagjai extrém alacsonynak bizonyultak, $8 \mathrm{E}$ degludek és $3 \times 2$ E glulizin inzulint kapott, ami 0,2 E/testsúlykgnak felelt meg.

A 24 órás gondozónőt egy hónap után elküldte, azt hangoztatva, hogy ha 86 éven át el tudta látni magát, akkor erre a továbbiakban is képes lesz. Mindvégig megtartott magas szintủ intellektusa e téren teljes csődöt vallott. Bár többször kijelentette, hogy nagyon szép élete volt, úgy vélte, eleget élt. A gondozónő távozása után egyre több idő́t töltött ágyában, hypostaticus pneumonia és bronchitis lépett fel nála, visszautasította a gyógyszerelést és a kórházi felvételt, és 23 nappal később - 2 hónappal 9l. életévének betöltését követően - lakásában összeesve elhunyt.

A sectio során halálokként a bal kamra sövényi falára lokalizált myocardialis infarctust, mellékleletként dilatativ cardiomyopathiát, hypostaticus pneumoniát és bronchitist, acut pulmonalis oedemát írtak le. A coronariákon lévő meszes plakkok helyenként a lument túhegynyire szúkítették. Az egész artériás rendszeren extrém fokú arteriosclerosist találtak.

\section{Megbeszélés}

l-es típusú diabetesben 86 éves diabetestartamot eddig nem közöltek. A jelen esetet ezen túlmenően abszolút egyedivé teszi, hogy e 86 éven belül az utolsó közel 56 éven keresztül a beteget egyetlen orvos gondozta. Joggal merül fel a kérdés: minek volt köszönhető az extrém hosszú diabetestartam?

A DCCT-EDIC vizsgálat [1] egyértelmúen igazolta azt a feltételezést, hogy a jó anyagcsere-vezetés csökkenti a mortalitás kockázatát és meghosszabbítja az élettartamot. Különösen a diabetes kezdetét követő glykaemiás kontroll játszik szerepet az l-es típusú diabetesesek mortalitásában, fóként gyermek- és serdülő́korban [10]. Ezen túlmenőn minél kisebb a glykaemiás variabilitás, annál jobb az esély a késői diabeteses szövődmények kivédésére [11].

Betegünk esetében diabetese első 50 évében - még az intenzív inzulinterápia és a vércukor-önellenőrzés bevezetése előtti időszakban - sem kiváló anyagcsere-vezetésről, sem kisfokú glykaemiás variabilitásról nem beszélhetünk. Ennek ellenkezőjét idézte elő a napi egyszeri, 
folyamatosan túldozírozott inzulinadagolás az 1940-es évek elejétől a hetvenes évek végéig. Anyagcseréjét csak ezt követően sikerült viszonylagosan stabilizálni, jóllehet az ismertetett okokból az inzulinkezelés abszolút afiziológiás változatát folytattuk. Elfogadható/jó anyagcserevezetésről csak a nyolcvanas évek közepétől beszélhetünk, mint azt az utolsó 25 évet illetően a $\mathrm{HbA}_{\mathrm{lc}}$-görbét ábrázoló 2. ábra mutatja. Kiemelendő még a saját inzulintermelés hiányában és jó vesefunkciók mellett rendkívül lecsökkent inzulinigénye. Mindezek ellenére a Bliss [7] által becsült 39,8 éves várható élettartam több mint a kétszeresére nőtt.

Tehát a szikár tények alapján nem találunk magyarázatot betegünk hosszú diabetestartamára és betegsége szövődményszegénységére. Családjában nem volt példa a hosszú élettartamra, ezért a beteg különleges genetikai adottságai tehetők felelőssé egyrészt az igen hosszú élettartamért, másrészt az igen kevés diabeteses szövődményért [12]. Egy másik fontos tény a beteg rezilienciája $[13,14]$, azaz különlegesen pozitív életszemlélete, életigenlése, minden veszteségből, betegségből történő gyors talpra állása és mindenekfelett roppant mértékü büszkesége önmagát, teljesítményeit illetően. Ha mindemellé hozzátesszük azt, hogy élete utolsó 55 évében egyetlen, odafigyelő és barátként minden problémájában segítő orvos gondozta, ez bizonyára nyom a latban, de csak a fentieket követően.

Megjegyzés: Az esetrôl rövid beszámolót írtunk a Jour nal of Clinical Diabetesben (J Clin Diabetes 3: e104).

Anyagi támogatás: A közlemény megírása anyagi támogatásban nem részesült.

A szerző a cikk végleges változatát elolvasta és jóváhagyta.

Érdekeltségek: A szerzőnek nincsenek érdekeltségei.

\section{Köszönetnyilvánítás}

Köszönöm dr. Kocsis Győzó föorvosnak, hogy egymás után hét alkalommal készséggel vette fel betegemet a Péterfy Sándor Utcai Kórház II Belosztályára, valamint köszönöm $d r$. Kóczi Zoltán föorvosnak a sectio Szent János Kórházban történt gondos elvégzését.

\section{Irodalom}

[1] The Diabetes Control and Complications Trial (DCCT)/Epidemiology of Diabetes Interventions and Complications (EDIC) Study Research Group. Mortality in type 1 diabetes in the DCCT/EDIC versus the general population. Diabetes Care 2016; 39: 1378-1383.

[2] Asao K, Sarti C, Forsen T, et al., for the Diabetes Epidemiology Research International (DERI) Mortality Study Group. Longterm mortality in nationwide cohorts of childhood-onset type 1 diabetes in Japan and Finland. Diabetes Care 2003; 26: 20372042.

[3] Secrest AM, Becker DJ, Kelsey SF, et al. All-cause mortality trends in a large population-based cohort with long-standing childhood-onset type 1 diabetes: the Allegheny County Type 1 Diabetes Registry. Diabetes Care 2010: 33: 2573-2579.

[4] Patterson CC, Dahlquist G, Harjutsalo V, et al. Early mortality in EURODIAB population-based cohorts of type 1 diabetes diagnosed in childhood since 1989. Diabetologia 2007; 50: 24392442 .

[5] Skrivarhaug T, Bangstad HJ, Stene LC, et al. Long-term mortality in a nationwide cohort of childhood-onset type 1 diabetic patients in Norway. Diabetologia 2006; 49: 298-305.

[6] Morgan E, Cardwell R, Black CJ, et al. Excess mortality in type $\mathrm{l}$ diabetes diagnosed in childhood and adolescence: a systematic review of population-based cohorts. Acta Diabetol. 2015; 52: 801-807.

[7] Bliss M. The discovery of insulin. Paul Harris, Edinburgh, 1983.

[8] Miller RG, Secrest AM, Sharma RK, et al. Improvements in the life expectancy of type 1 diabetes. The Pittsburgh Epidemiology of Diabetes Complications Study Cohort. Diabetes 2012; 61: 2987-2992.

[9] The Medalist Program and Study at Joslin recognizes and studies people who have been living with diabetes for more $50+$ years. Joslin Diabetes Center, Boston, MA. Available from: https:// www.joslin.org/research/our-research/medalist-program-study [accessed: October 15, 2019].

[10] Mameli C, Mazzantini S, Ben Nasr M, et al. Explaining the increased mortality in type 1 diabetes. World J Diabetes 2015; 6: 889-895.

[11] Hirsch IB. Glycemic variability and diabetes complications: does it matter? Of course it does! Diabetes Care 2015; 38: 16101614

[12] Sebastiani P, Solovieff N, DeWan AT, et al. Genetic signatures of exceptional longevity in humans. PLoS ONE 2012; 7: e29848.

[13] Mari D. The art of ageing well. [Az aktív időskor múvészete, avagy séta százévesekkel.] Corvina Kiadó, Budapest, 2018.

[14] Yi-Frazier JP, Smith RE, Vitaliano PP, et al. A person-focused analysis of resilience resources and coping in patients. Stress Health 2010; 26: 51-60.

(Fövényi József dr., Budapest, Péterfy Sándor u. 8-20., 1076 e-mail: j.fovenyi@gmail.com)

A cikk a Creative Commons Attribution 4.0 International License (https://creativecommons.org/licenses/by/4.0/) feltételei szerint publikált Open Access közlemény, melynek szellemében a cikk bármilyen médiumban szabadon felhasználható, megosztható és újraközölhetö, feltéve, hogy az eredeti szerző és a közlés helye, illetve a CC License linkje és az esetlegesen végrehajtott módositások feltüntetésre kerülnek. (SID_1) 